\title{
Differential expression of IGF-1 mRNA isoforms in colorectal carcinoma and normal colon tissue
}

\author{
ALDONA KASPRZAK ${ }^{1}$, WITOLD SZAFLARSKI ${ }^{1}$, JACEK SZMEJA ${ }^{2}$, MAŁGORZATA ANDRZEJEWSKA ${ }^{1}$, \\ WIESŁAWA PRZYBYSZEWSKA ${ }^{1}$, ELŻBIETA KACZMAREK ${ }^{3}$, MARIA KOCZOROWSKA ${ }^{4}$, \\ TOMASZ KOŚCIŃSKI ${ }^{2}$, MACIEJ ZABEL ${ }^{1}$ and MICHAŁ DREWS ${ }^{2}$ \\ Departments of ${ }^{1}$ Histology and Embryology, ${ }^{2}$ General, Gastroenterological and Endocrinological Surgery and \\ ${ }^{3}$ Bioinformatics and Computational Biology, Chair of Pathology, Poznan University of Medical Sciences; \\ ${ }^{4}$ Department of Molecular Virology, Adam Mickiewicz University, Poznań, Poland
}

Received September 5, 2012; Accepted November 2, 2012

DOI: $10.3892 /$ ijo.2012.1706

\begin{abstract}
The insulin-like growth factor $(I G F)-1$ gene consists of 6 exons resulting in the expression of 6 variant forms of mRNA (IA, IB, IC, IIA, IIB and IIC) due to an alternative splicing. The mechanisms of $I G F-1$ gene splicing and the role of local expression manifested by IGF-1 mRNA variants in colorectal carcinoma (CRC) have not been extensively investigated. Therefore, the aim of our study was to analyse the expression of IGF-1 mRNA isoforms [A, B, C, P1 (class I) and P2 (class II)], as well as the protein expression in CRC and control samples isolated from 28 patients. The expression of Ki-67 was also analysed and clinical data were obtained. For this purpose, we used quantitative real-time PCR (qPCR) and immunocytochemistry. The expression of mRNAs coding for all splicing isoforms of $I G F-1$ was observed in every tissue sample studied, with a significantly lower expression noted in the CRC as compared to the control samples. The cytoplasmic expression of IGF-1 protein was found in $50 \%$ of the CRC and in $\sim 40 \%$ of the non-tumor tissues; however, no significant quantitative inter-group differences were observed. The expression of the $I G F-1$ gene in the 2 groups of tissues was controlled by the $\mathrm{P} 1$ and $\mathrm{P} 2$ promoters in a similar manner. No significant differences were detected in the expression of the IGF-1 A and B isoforms; however, their expression was significantly higher compared to that of isoform C. No significant differences were observed between the expression of Ki-67 mRNA in the CRC and control tissue even though the expression of the $\mathrm{Ki}-67$ protein was higher in the CRC compared to the control samples. Ki-67 protein expression was associated
\end{abstract}

Correspondence to: Professor Aldona Kasprzak, Department of Histology and Embryology, Poznan University of Medical Sciences, Święcickiego 6, 60-781 Poznań, Poland

E-mail: akasprza@ump.edu.pl

Key words: colorectal carcinoma, insulin-like growth factor isoforms, quantitative real-time PCR, immunocytochemistry with the macroscopic and microscopic aspects of CRC. A significant positive correlation was found between the local production of total mRNA and isoform $A$ and the expression of Ki-67 mRNA, although only in the non-tumor tissues. In CRC samples, the local expression of the total IGF-1 mRNA and all splicing isoforms of IGF-1 mRNA decreased as compared to the normal colon tissues, although however, with conservation of both gene promoter activities and with the continued principal splicing IGF-1 mRNA isoforms.

\section{Introduction}

The role of the insulin-like growth factor (IGF) system in carcinogenesis, including colorectal cancer (CRC) has been extensively described in the literature (1-4). The local overproduction of IGF-1 and IGF-2 has been found in 'endocrine-dependent' cancers (breast and prostate) and other tumors (lung, colon). This suggests that both proteins may play a role in neoplastic growth in situ (4-6). Epidemiological data have indicated that high serum concentrations of IGF-1 and low levels of the IFG binding protein 3 (IGF BP-3) are associated with an increased risk of several types of carcinoma (including colon) which are common in economically developed countries $(3,4,7,8)$. Nevertheless, both earlier results (9) and recent prospective studies using meta-analysis have pointed toward a relatively modest positive association of CRC risk with serum IGF-1 concentration (10). Thus, the role of increased serum IGF-1 levels as key regulators of CRC risk seems controversial $(2,3,9,10,11)$. New factors related to IGF-associated metabolic pathways are being investigated in order to determine the risk of CRC development and to prevent the development of colon cancer.

IGF-1 is a peptide growth factor which stimulates postnatal somatic growth and maintains lean tissue mass as an endocrine hormone. It has also been demonstrated to exert autocrine and paracrine effects in several tissues $(12,13)$. In the circulation, over $90 \%$ of IGF-1 is bound to IGF BP-3 forming a $150 \mathrm{kDa}$ complex which is not able to cross the vascular endothelium. By contrast, free IGF-1 is able to diffuse into tissues and perform its biological functions $(13,14)$. 
The $I G F-1$ gene is present in the human genome as a single copy with 6 exons and 5 introns $(15,16)$. The exons of $I G F-1$ are alternatively spliced in multiple transcripts encoding specific blood-circulating and tissue-specific isoforms of the IGF-1 peptide $(17,18)$. The alternative splicing regulates the expression of the 2 promoters, $\mathrm{P} 1$ or $\mathrm{P} 2$, which results in 2 different classes of IGF-1 isoforms, i.e., class I (1) and class II (2), $(19,20)$. Furthermore, alternative splicing gives rise to at least 3 subsets of RNA transcripts at the $3^{\prime}$ end of the gene, each encoding 3 distinct carboxy-terminal portions of the unique E-domain extension-peptide (E-peptide) as well as the 3'-untranslated region (3'UTR) (15,21-23). Exon 3 encodes parts of the signal peptide and the mature peptide which is common to all isoforms, while exon 4 encodes the rest of the mature peptide and the proximal part of the E-domain. The expression and composition of nucleotides in exons 5 and 6 determine the formation of isoform variants: $\mathrm{A}(\mathrm{Ea}), \mathrm{B}(\mathrm{Eb})$ and $\mathrm{C}(\mathrm{Ec})$ within classes I and II (17) (Fig. 1). The predominant transcript, IGF-1Ea, has exon 4 spliced directly to exon 6 . The insertion of exon 5 results in 2 transcript variants in humans: IGF-1Ec (IGF-1b in rodents) [mechano growth factor, (MGF)] and IGF-1Eb $(17,18,24)$. The variant designated as IGF-1Eb has only been observed in humans and it contains mRNA with exon 5 spliced to exon 4 (25). It comprises $\sim 10 \%$ of the total $I G F-1$ expression (24).

The expression of IGF-1 mRNA isoforms determines various isoforms of the IGF-1 protein $(17,18)$. Peptide Ea which is composed of 35 amino acids is spliced out from the $\mathrm{C}$ terminal region of premature IGF-1 (i.e., pre-protein). It may be responsible for both mitogenic (26) and inhibitory effects on cancer cell growth (27). Furthermore, peptide Eb, which is composed of Eb1 and Eb2 peptides may exert mitogenic effects on IGF-1 independently; however, the activity of both peptides differs in various types of tissue (28). Peptide Ec (MGF) was originally identified in the liver, while higher amounts have been found in muscle following training $(29,30)$. The isoform plays a critical role in the development, growth and repair of the skeletal muscle $(18,29,30)$ and it protects cardiomyocytes from oxidative and hypertrophic stress via SirT1 activity (31). The mature molecule of IGF-1 is encoded exclusively by exons 3 and 4. IGF-1 secretion to the vascular bed is represented by the peptide variant of IGF-1Ea (23).

In mammals, the transcription of the $I G F-1$ gene is controlled by 2 promoters (P1 and $\mathrm{P} 2$ ) which are located before exons 1 and 2 , respectively $(16,32)$. Furthermore, the P1 promoter initiates over $90 \%$ of transcripts in mammals (33). It is thought that the P2 promoter encodes the endocrine IGF-1 form which remains under the control of growth hormone $(\mathrm{GH})(16)$. The biochemical mechanisms controlling the usage of IGF-I promoters remains unclear.

IGF-1 stimulates cell growth in vitro by the activation of proliferation and by the inhibition of apoptosis in cancer cells (2,34-36). The administration of recombinant human IGF-1 (rhIGF-1) has been shown to cause intensive cecal tumor growth, increased tumor mass and a higher rate of hepatic metastases (8). IGF-1 may be responsible for more invasive colon cancer with higher metastatic potential since IGF-1 causes the higher motility and migration of cancer cells and stimulates vascular endothelial growth factor (VEGF) expression $(37,38)$. The complex role of the different IGF-1 isoforms in carcinogenesis has not yet been fully elucidated (39-41).
In the present study, we further investigated the tissue expression of total IGF-1 mRNA, IGF-1 mRNA isoforms (IGF-1A, IGF-1B and IGF-1C) and $I G F-1$ gene promoters (P1 and $\mathrm{P} 2$ ). We demonstrate the differences between the CRC samples in comparison to normal colon tissue. The expression of both IGF-1 isoforms and Ki-67 was also compared to clinical data.

\section{Materials and methods}

Patients and tissue material. The examined CRC group included 28 patients ( 22 males, 6 females), 32 to 89 years of age (mean, 65 \pm 11 years) from the Department of General, Gastroenterological and Endocrinological Surgery, Poznan University of Medical Sciences in Poznań, who were diagnosed and subjected to surgery between September 2010 and September 2011. A total of 28 paired specimens of colorectal tumor and non-tumor tissues were obtained during surgical treatment. For CRC, colon mucosa and, depending on the depth of tumor invasion, submucosal layers $\sim 15 \mathrm{~cm}$ from the tumor site served as the control tissues. No additional tissue was removed from the patients apart from that which is normally removed during surgical procedures. The tumor samples consisted of 1 adenocarcinoma in situ, 3 adenocarcinomas with muscularis propria invasion (pT2), 23 adenocarcinomas with muscularis propria invasion into pericolorectal tissue (pT3), and 1 adenocarcinoma with tumor penetration to the surface of the visceral peritoneum [pT4 in the tumor-nodemetastasis (TNM) classification of the International Union Against Cancer]. Two patients had metastases to the liver. The locations of the colorectal tumors were divided into proximal colon (cecum, ascending and transverse colon) and distal colon (descending, sigmoid colon and rectum). Macroscopic types were divided into protruded type (height of tumor $\geq 3 \mathrm{~mm}$ ) and flat type (height of tumor, $<3 \mathrm{~mm}$ ). The clinicopathological characteristics of the colorectal tumors are shown in Table I.

The tissue samples were stored in RNA Stabilization Solution (RNAlater ${ }^{\circledR}$, Applied Biosystems) at $-80^{\circ} \mathrm{C}$ until use. Additionally, formalin-fixed paraffin-embedded tumor specimens of $28 \mathrm{CRC}$ and fragments of the confirmed control specimens were obtained from patients. Histopathological analysis of the CRC samples confirmed the presence of 27 colonic adenocarcinomas (20 patients with G2, 7 patients with G3 grade), and 1 patient with colonic adenocarcinoma in situ. A total of 17 patients were of Dukes' C stage, 8 of Dukes' B stage, and 3 of Dukes' A stage (Table I). Informed consent was obtained from each subject, and the institutional review committee approved this study.

Immunocytochemical analyses. Tissue sections of $5 \mu \mathrm{m}$ in thickness were deposited onto SuperFrost/Plus microscope slides. In order to qualify the material for the study, routine staining of the sections with H\&E was performed. For detection and cellular localization of IGF-1 and Ki-67 antigen, anti-human mouse monoclonal antibodies (MAbs) specific for IGF-1 (R\&D Systems; in dilution 1:500) and the human Ki-67 antigen (clone MIB-1) (DAKO, 1:2) were used, as well as the classical ABC (streptavidin-biotin-peroxidase complex), according to the methods described in the study by Hsu et al (42) and in our previous study (41). The preparations were 

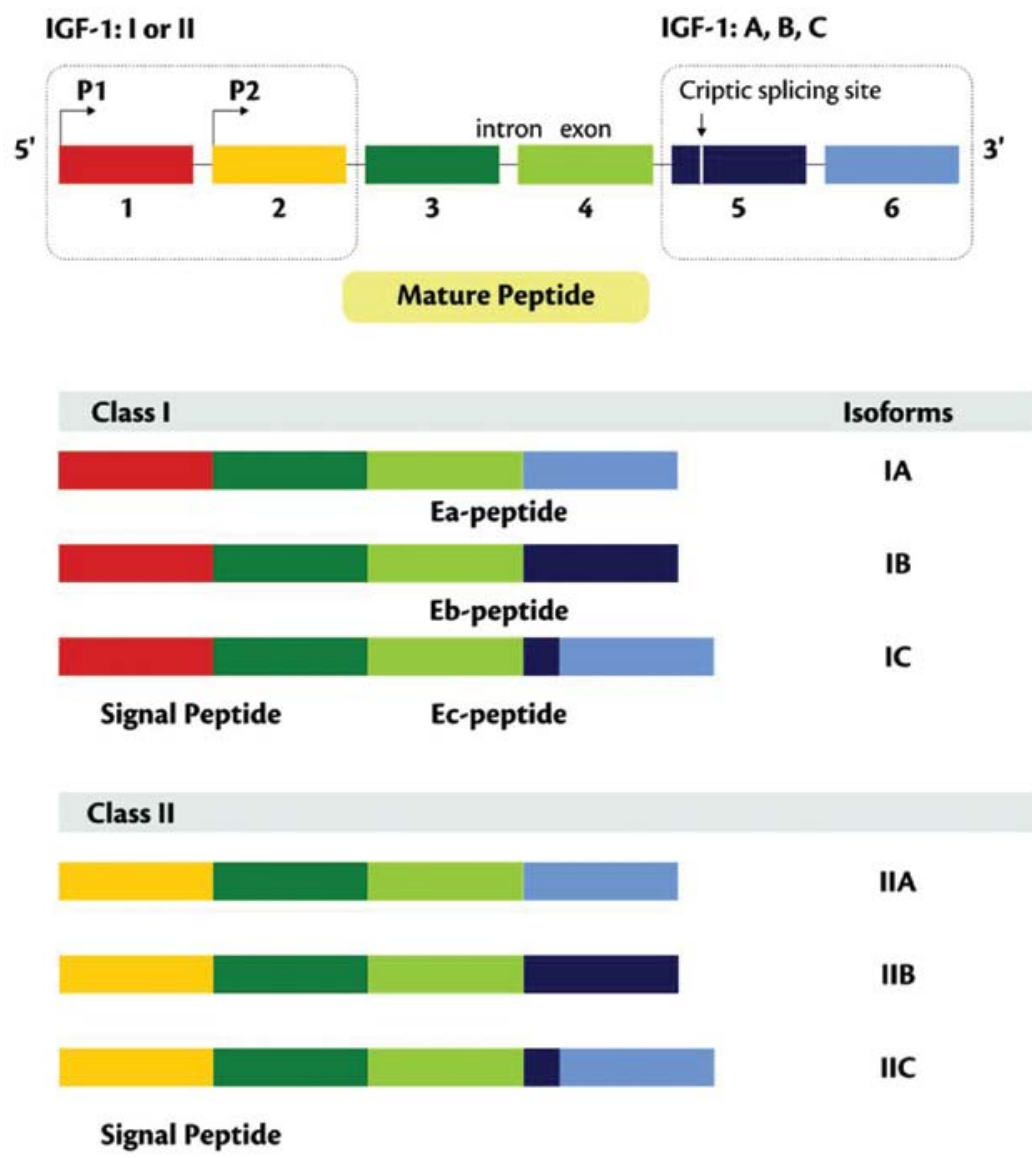

Figure 1. Structure of the human $I G F-1$ gene, its mRNA isoforms generated by alternative splicing and encoded precursor peptides. The human $I G F-1$ gene is composed of 6 exons. Transcription starts from one of the two promoters (P1 and P2) located in exon 1 and 2 , respectively. Exons 1 and 2 are alternatively utilized and comprise class I and II, respectively. Exons 3 and 4 are expressed in all known isoforms. Exon 5 is normally absent (isoform A) but when is included, it forms isoform B or isoform C. mRNAs containing exon 4 spliced directly to exon 6 are designed also as Ea, those containing exon 5 spliced to exon 4 are designed as Eb. The IGF-1Ec splice variant is an exon 4-5-6 variant. All peptide products, derived from pro-IGF-1 are shown (17,18).

counterstained using hematoxylin. Each experiment included internal negative controls in which specific antibodies were substituted by sera of a respective species in $0.05 \mathrm{M}$ Tris- $\mathrm{HCl}$, $\mathrm{pH} 7.6$, supplemented with $0.1 \%$ bovine albumin (BSA) and $15 \mathrm{mM}$ sodium azide.

Semi-quantitative evaluation of IGF-1 protein and $\mathrm{Ki}-67$ antigen expression. IGF-1 protein expression was analysed by 2 pathologists employing the semi-quantitative IRS scale, according to the method described by Remmele and Stegner (43), taking into account the number of positive cells (PP) and intensity of the colour reaction (SI). The final score represented a product of scores representing the 2 variables (PPxSI) and ranged from 0 to 12 points. The final value of the PPXSI product ranging between 1 and 2 points characterised a faint, 3-4 a moderate and 6-12 an intense immunocytochemical reaction. In each preparation 10 visual fields of an Olympus $\mathrm{BH}-2$ light microscope were examined, under a x40 objective lens, and the mean scores were calculated.

The expression of Ki-67 proliferation-associated antigen (only clearly labelled cell nuclei were considered), was calculated taking into account the mean proportion of immunopositive cells in 10 light microscope fields. Expression was evaluated using the semi-quantitative scale of Gatter et al (44), in which the score of 1 corresponded to up to $10 \%$ positive cells; the scores of 2, 3 and 4 corresponded to 11-25, 26-50 and $\geq 51 \%$ positive cells, respectively.

Isolation of total RNA and synthesis of cDNA. The total RNA fraction was prepared using TRI Reagent ${ }^{\circledR}$ Solution (Applied Biosystems) and, it was then purified using the GeneMATRIX Universal RNA Purification kit (EURx). The quantity of total RNA was determined by optical density at $260 \mathrm{~nm}$ and its purity was estimated by $260 / 280 \mathrm{~nm}$ absorption ratio, which was consistently $>1.8$ (NanoDrop ${ }^{\circledR}$ ND-1000; ThermoScientific). RNA integrity was assessed by electrophoresis on a $1 \%$ agarose gel with ethidium bromide. All RNA samples were stored in $\mathrm{H}_{2} \mathrm{O}$ at $-80^{\circ} \mathrm{C}$ until use.

Reverse transcription was carried out on $1.0 \mu \mathrm{g}$ of total RNA following the manufacturer's instructions (First-strand cDNA synthesis kit, Fermentas). Template RNA, random hexamer primers $(1 \mu \mathrm{l})$ and diethylpyrocarbonate (DEPC)treated water were mixed together to a total volume of $11 \mu \mathrm{l}$ and pre-incubated at $65^{\circ} \mathrm{C}$ for $5 \mathrm{~min}$ in a Biometra thermocycler. The samples were then chilled on ice, centrifuged and moved to fresh PCR tubes in order to prevent permeability of the cup. Subsequently, 5X reaction buffer $(4 \mu \mathrm{l})$, RiboLock ${ }^{\mathrm{TM}}$ RNase inhibitor $20 \mathrm{U} / \mu \mathrm{l}(1 \mu \mathrm{l}), 10 \mathrm{mM}$ dNTP mix $(2 \mu \mathrm{l})$ and M-MuLV reverse transcriptase $20 \mathrm{U} / \mu \mathrm{l}(2 \mu \mathrm{l})$ were added to the pre-incubated solution, mixed by pipetting and incubated 
Table I. Clinicopathological characteristics of the 28 patients with colorectal tumors.

\begin{tabular}{|c|c|c|c|c|c|c|c|c|c|c|c|}
\hline Case & Age & Gender & Location & $\begin{array}{l}\text { Macroscopic } \\
\text { type }\end{array}$ & $\begin{array}{l}\text { Microscopic } \\
\text { type }\end{array}$ & $\mathrm{T}$ & $\mathrm{N}$ & M & Grading & $\begin{array}{l}\text { Dukes' } \\
\text { stage }\end{array}$ & $\begin{array}{l}\text { Astler-Coller } \\
\text { stage }\end{array}$ \\
\hline 1 & 89 & M & $\mathrm{P}$ & F & 3 & 3 & 1 & 0 & 3 & $\mathrm{C}$ & $\mathrm{C} 2$ \\
\hline 2 & 78 & $\mathrm{M}$ & D & $\mathrm{P}$ & 1 & 3 & 2 & 0 & 2 & $\mathrm{C}$ & $\mathrm{C} 2$ \\
\hline 3 & 53 & M & $\mathrm{P}$ & $\mathrm{P}$ & 1 & 3 & 0 & 0 & 2 & $\mathrm{~B}$ & B2 \\
\hline 4 & 56 & M & $\mathrm{D}$ & F & 1 & 3 & 1 & 0 & 2 & $\mathrm{C}$ & $\mathrm{C} 2$ \\
\hline 5 & 75 & M & $\mathrm{D}$ & $\mathrm{P}$ & 0 & 0 & 0 & 0 & & A & A \\
\hline 6 & 56 & F & $\mathrm{D}$ & $\mathrm{P}$ & 1 & 3 & $1 b$ & 0 & 2 & $\mathrm{C}$ & $\mathrm{C} 2$ \\
\hline 7 & 68 & M & $\mathrm{P}$ & $\mathrm{P}$ & 2 & 3 & $2 b$ & 0 & 3 & $\mathrm{C}$ & $\mathrm{C} 2$ \\
\hline 8 & 77 & M & $\mathrm{P}$ & $\mathrm{P}$ & 2 & 3 & $2 b$ & 0 & 3 & $\mathrm{C}$ & $\mathrm{C} 2$ \\
\hline 9 & 69 & M & $\mathrm{D}$ & $\mathrm{P}$ & 2 & 3 & 0 & 0 & 2 & B & B2 \\
\hline 10 & 67 & $\mathrm{~F}$ & $\mathrm{D}$ & F & 1 & 3 & 1 & 0 & 2 & $\mathrm{C}$ & $\mathrm{C} 2$ \\
\hline 11 & 51 & M & $\mathrm{P}$ & $\mathrm{P}$ & 3 & 2 & 1 & 0 & 2 & $\mathrm{C}$ & $\mathrm{C} 1$ \\
\hline 12 & 64 & $\mathrm{~F}$ & $\mathrm{D}$ & F & 1 & 3 & 2 & 0 & 2 & $\mathrm{C}$ & $\mathrm{C} 2$ \\
\hline 13 & 32 & M & $\mathrm{P}$ & $\mathrm{P}$ & 1 & 3 & 1 & 0 & 2 & $\mathrm{C}$ & $\mathrm{C} 2$ \\
\hline 14 & 64 & M & $\mathrm{P}$ & F & 1 & $4 b$ & 0 & 0 & 2 & $\mathrm{C}$ & $\mathrm{C} 2$ \\
\hline 15 & 72 & $\mathrm{~F}$ & $\mathrm{P}$ & $\mathrm{P}$ & 1 & 3 & 2 & 0 & 2 & $\mathrm{C}$ & $\mathrm{C} 2$ \\
\hline 16 & 58 & $\mathrm{M}$ & $\mathrm{D}$ & F & 1 & 3 & 1a & 0 & 2 & $\mathrm{C}$ & $\mathrm{C} 2$ \\
\hline 17 & 72 & $\mathrm{M}$ & $\mathrm{D}$ & F & 1 & 2 & 0 & 0 & 2 & A & B1 \\
\hline 18 & 63 & $\mathrm{M}$ & $\mathrm{D}$ & $\mathrm{P}$ & 2 & 3 & $2 b$ & 0 & 3 & $\mathrm{C}$ & $\mathrm{C} 2$ \\
\hline 19 & 77 & $\mathrm{M}$ & $\mathrm{P}$ & F & 1 & 3 & 0 & 0 & 3 & B & B2 \\
\hline 20 & 55 & $\mathrm{M}$ & $\mathrm{D}$ & F & 2 & 3 & $1 b$ & 1 & 3 & $\mathrm{C}$ & $\mathrm{C} 2$ \\
\hline 21 & 74 & $\mathrm{M}$ & $\mathrm{P}$ & F & 2 & 3 & 1a & 0 & 2 & $\mathrm{C}$ & $\mathrm{C} 2$ \\
\hline 22 & 52 & $\mathrm{M}$ & $\mathrm{D}$ & F & 1 & 3 & 0 & 0 & 2 & B & B2 \\
\hline 23 & 54 & $\mathrm{M}$ & $\mathrm{D}$ & $\mathrm{P}$ & 1 & 3 & 1a & 0 & 2 & $\mathrm{C}$ & $\mathrm{C} 2$ \\
\hline 24 & 77 & M & $\mathrm{P}$ & $\mathrm{P}$ & 1 & 3 & 0 & 0 & 2 & B & B1 \\
\hline 25 & 73 & $\mathrm{M}$ & $\mathrm{D}$ & F & 3 & 2 & 0 & 0 & 2 & A & B1 \\
\hline 26 & 63 & $\mathrm{~F}$ & $\mathrm{P}$ & $\mathrm{P}$ & 1 & 3 & 0 & 0 & 2 & B & B2 \\
\hline 27 & 65 & F & D & F & 2 & 3 & 0 & 1a & 3 & B & B2 \\
\hline 28 & 75 & $\mathrm{M}$ & D & $\mathrm{P}$ & 3 & 3 & 0 & 0 & 2 & B & B2 \\
\hline
\end{tabular}

M, male; F, female. Location: P, proximal; D, distal. Macroscopic type: P, protruded; F, flat. Microscopic type: 0, adenocarcinoma in situ; 1, tubulous adenocarcinoma; 2, mucinous/partial mucinous adenocarcinoma; 3 , tubulovillous adenocarcinoma.

at $42^{\circ} \mathrm{C}$ for $60 \mathrm{~min}$ (Biometra thermocycler). Finally, cDNA was stored in $\mathrm{H}_{2} \mathrm{O}$ at $-20^{\circ} \mathrm{C}$ or immediately used for subsequent amplification reactions.

\section{Absolute quantification of $m R N A$ copies}

Preparation of standard curves for a copy number determination. cDNA of all IGF-1 isoforms (P1, P2, A, B, C, separately), (Fig. 1) was amplified using standard PCR and specific primers (Table II). PCR products were analysed on a $2 \%$ agarose gel in order to confirm their specificity and, then, all PCR products were purified separately using the GeneMATRIX PCR/ DNA Clean-up purification kit (EURx). The concentration of each DNA was estimated by measuring the optical density at 260 nm (NanoDrop ${ }^{\circledR}$ ND-1000, ThermoScientific). The weight concentrations were converted to the corresponding DNA copy numbers using the Avogadro constant:

$$
\text { DNA (copy) }=\frac{6.02 \times 10^{23}\left(\text { copies mol }{ }^{-1}\right) \times \text { DNA amount }(\mathrm{g})}{\text { DNA length }(\mathrm{bp}) \times 660\left(\mathrm{gmol}^{-1} \mathrm{bp}^{-1}\right)}
$$

A 10-fold serial dilution of corresponding DNA and specific primers, ranging from $1 \times 10^{7}$ to 10 copies per $\mu 1$, were used to construct the standard curves. Threshold cycle $\left(C_{t}\right)$ values in each dilution were measured in duplicates and were plotted against the logarithm of their initial template copy numbers. Each standard curve was generated by a linear regression of the plotted points. From the slope of each curve, PCR amplification efficiency $(E)$ was calculated according to the following equation: $\mathrm{E}=10^{-1 / \text { slope }}-1$.

Real-time PCR reaction. A total of $1 \mu \mathrm{l}$ of a given cDNA or DNA was added to the reaction mixture, composed of $12.5 \mu 12 X$ Maxima ${ }^{\circledR}$ SYBR-Green/ROX qPCR Master mix (Fermentas), $1 \mu \mathrm{l}$ specific pair of primer (f.c. $0.3 \mu \mathrm{M}$ ) and $10.5 \mu 1 \mathrm{H}_{2} \mathrm{O}$. Primers for experiments on the expression of vault-related gene and reference genes were taken either from Koczorowska et al (40) or designed by ourselves (Table II) and purchased from the Laboratory of DNA Sequencing and Oligonucleotide Synthesis, Institute of Biochemistry and Biophysics, Polish Academy of Sciences, Warsaw, Poland. 
Table II. Primer sequences used in real-time PCR and PCR product sizes.

\begin{tabular}{|c|c|c|c|}
\hline Target & NCBI accession no. & Product lenghth (bp) & Sequence \\
\hline $\begin{array}{l}\text { Class I (1) } \\
\text { IGF-1 P1 }\end{array}$ & NM_001111283 & 102 & $\begin{array}{l}\text { 5'-CAGCAGTCTTCCAACCCA (F) } \\
\text { 5'-CACAGCGCCAGGTAGAAGAGATGC (R) }\end{array}$ \\
\hline $\begin{array}{l}\text { Class II (2) } \\
\text { IGF-1 P2 }\end{array}$ & NM_001111284 & 101 & $\begin{array}{l}\text { 5'-CACCTACAGTGAAGATGCACACC (F) } \\
\text { 5'-CGTCTCCGGTCCAGCCGTGGC (R) }\end{array}$ \\
\hline IGF-1 A & NM_001111284 & 144 & $\begin{array}{l}\text { 5'-TCGTGGATGAGTGCTGCTTCCG (F) } \\
\text { 5'-TCAAATGTACTTCCTTCTGGGTCTTG (R) }\end{array}$ \\
\hline IGF-1 B & NM_001111285 & 141 & $\begin{array}{l}\text { 5'-CTCGCTCTGTCCGTGCCC (F) } \\
\text { 5'-CCCCTCCTTCTGTTCCCCTCC (R) }\end{array}$ \\
\hline IGF-1 C & NM_001111283 & 126 & $\begin{array}{l}\text { 5'-ACCAACAAGAACACGAAGTC (F) } \\
\text { 5'-CATGTCACTCTTCACTCCTC (R) }\end{array}$ \\
\hline IGF-1 total & $\begin{array}{l}\text { NM_001111283 } \\
\text { NM_001111284 } \\
\text { NM_001111285 }\end{array}$ & 160 & $\begin{array}{l}\text { 5'-CATGTCCTCCTCGCATCTCT (F) } \\
\text { 5'-ATACCCTGTGGGCTTGTTGA (R) }\end{array}$ \\
\hline $\mathrm{Ki}-67$ & NM_001145966 & 168 & $\begin{array}{l}\text { 5'-CTGCTTGTTTGGAAGGGGTA (F) } \\
\text { 5'-AGCCGTACAGGCTCATCAAT (R) }\end{array}$ \\
\hline$\beta-A C T$ & NM_001101 & 169 & $\begin{array}{l}\text { 5'-TCTGGCACCACACCTTCTAC (F) } \\
\text { 5'-GATAGCACAGCCTGGATAGC (R) }\end{array}$ \\
\hline$B 2 M$ & NM_004048 & 137 & $\begin{array}{l}\text { 5'-CTCACGTCATCCAGCAGAGA (F) } \\
\text { 5'-AAGACAAGTCTGAATGCTCCA (R) }\end{array}$ \\
\hline$G A P D H$ & NM_002046 & 199 & $\begin{array}{l}\text { 5'-GAAGGTGAAGGTCGGAGTCA (F) } \\
\text { 5'-CTGAGAACGGGAAGCTTGTC (R) }\end{array}$ \\
\hline HPRTI & NM_000194 & 156 & $\begin{array}{l}\text { 5'-CTGAGGATTTGGAAAGGGTG (F) } \\
\text { 5'-AATCCAGCAGGTCAGCAAAG (R) }\end{array}$ \\
\hline MRPL19 & NM_014763 & 171 & $\begin{array}{l}\text { 5'-ACTTTATAATCCTCGGGTC (F) } \\
\text { 5'-ACTTTCAGCTCATTAACAG (R) }\end{array}$ \\
\hline
\end{tabular}

The reactions were driven in twin.tec real-time PCR plates with PCR Film (Eppendorf) using Mastercycler ep-realplex ${ }^{2}$ (Eppendorf). The PCR program was as follows: i) initial denaturation, $95^{\circ} \mathrm{C}, 10 \mathrm{~min}$; (ii denaturation, $95^{\circ} \mathrm{C}, 15 \mathrm{sec}$; iii) annealing $60^{\circ} \mathrm{C}, 30 \mathrm{sec}$; and iv) extension $72^{\circ} \mathrm{C}, 30 \mathrm{sec}$. The number of cycles was 40-50. Melting curves were made and $2 \%$ agarose gel electrophoresis was used to verify the amplification product specificity and size, respectively. All samples were amplified in duplicate or triplicate and in the case when the results varied by $>15 \%$ the reactions were repeated.

Absolute quantification using real-time PCR. The absolute quantification method was used to quantify mRNA copy numbers of all IGF-1 mRNA isoforms (P1, P2, A, B, C, separately) (Fig. 1). Absolute quantification determines the exact copy concentration of a target gene by relating the $C_{t}$ value to a standard curve. Prior to absolute quantification, the $\mathrm{C}_{t}$ values were normalised by comparison to the average of $\mathrm{C}_{\mathrm{t}}{ }_{\mathrm{t}} \mathrm{s}$ obtained for 5 housekeeping genes ( $\beta$-actin, B2M, GAPDH, HPRT1 and MRLP19). Evaluation of alterations in the expression of IGF-1 mRNA isoforms involved a comparison of mRNA copy numbers for those isoforms per $\mu \mathrm{g}$ RNA between tumor and control samples.

Statistical analysis. First, summary statistics were used to summarise the observations (arithmetic mean, standard devia- tion). Non-parametric statistical analysis of our data was carried out using the Friedman test for multiple dependent samples and the Mann-Whitney test for unpaired samples (tumor and control). Spearman's and Pearson's rank correlation was applied to examine the association between variables. Differences between percentages of IGF-1 mRNA isoforms in the tumor and control samples were assessed by the test for the comparison of fractions. Differences and correlations were assumed to be statistically significant at the level of $\mathrm{p}<0.05$. Statistical analysis was performed using the Statistica PL v.10 software.

\section{Results}

Immunocytochemical localization of IGF-1 and Ki-67 proteins. Immunocytochemical analyses demonstrated the cellular expression of the IGF-1 protein in 14 out of $28(50 \%)$ samples of CRC. Extensive individual differences were found in the intensity of the reaction, ranging from individual immunopositive cells to an intense, diffuse reaction in the majority of neoplastic cells. In non-tumor samples (control) positive IGF-1-cells were detected in 11 out of 28 (39\%) samples. The expression was detected in a cytoplasm of both neoplastic cells manifesting a variable size and shape and normal cells of intestinal crypts and/or connective tissue stroma cells and individual cells of inflammatory infiltrates (Fig. 2A and B). 


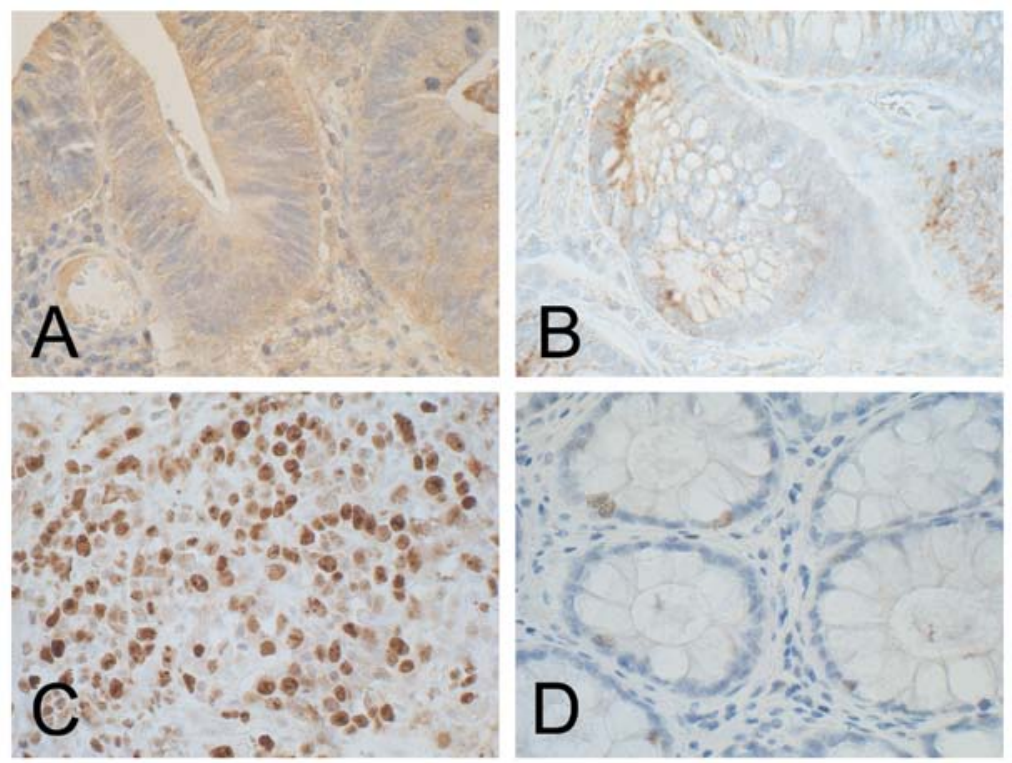

Figure 2. Cytoplasmic expression of IGF-1 protein in (A) a colorectal tissue sample and (B) in a control sample. Ki-67 protein expression in numerous cell nuclei in (C) a CRC sample and (D) in a control colon tissue sample. ABC method. Hematoxylin counterstaining. Objective magnification, $\mathrm{x} 40$.

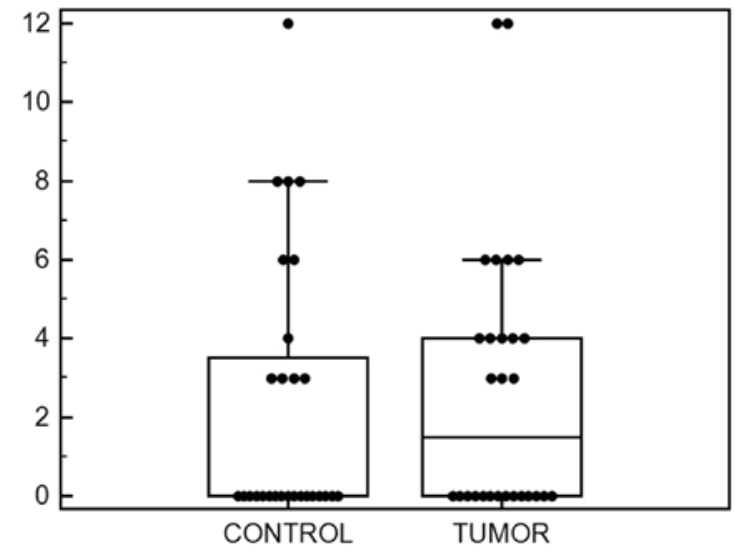

Figure 3. Expression of IGF-1 protein in non-tumor tissue (control), compared to CRC samples. Tissue expression was evaluated in the 12-point IRS scale, as described in Materials and methods (43); $>0.05$.

In both groups of examined tissues, the expression of IGF-1 manifested a moderate intensity (with the mean below 3 points in the IRS scale) and no quantitative differences were observed between the control and CRC samples $(2.29 \pm 3.41$ vs. $2.75 \pm 3.48$, respectively) (Fig. 3). The nuclear expression of the Ki-67 antigen (Fig. 2C and 2D) was noted in 25 out of $28(89 \%)$ CRC samples and in 24 out of $28(86 \%)$ control tissue samples. A significantly higher expression of Ki-67 was detected in the CRC samples $(2.79 \pm 1.32)$ in comparison to the

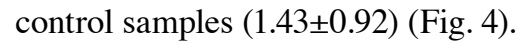

Expression of various IGF-1 mRNA isoforms. All known IGF-1 mRNA isoforms determined by class I (P1), class II (P2), A, B and $\mathrm{C}$ transcript expression were identified in the control and cancerous samples using the real-time PCR technique.

Non-tumor samples (control). In the non-tumor samples, statistically insignificant amounts of P1 and P2 mRNA

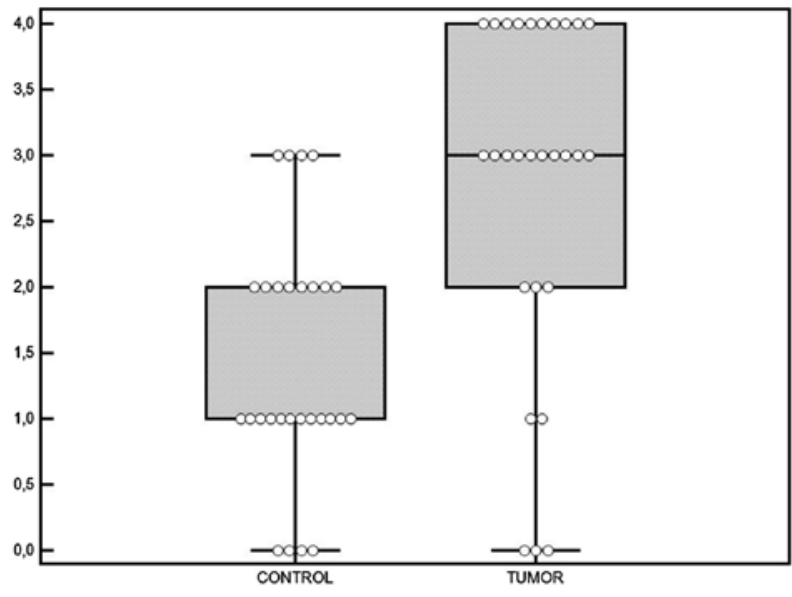

Figure 4. Expression of Ki-67 antigen in the control compared to tumor samples. Tissue expression was evaluated in the 4-point scale as described in Materials and methods (44); $\mathrm{p}<0.001$.

isoforms were found ( $>0.05$ ) (Fig. 5). Among the A, B and $\mathrm{C}$ isoforms, both $\mathrm{A}$ and $\mathrm{B}$ (with no significant differences between them) demonstrated a higher expression when compared to isoform $\mathrm{C}$ ( $\mathrm{p}<0.01, \mathrm{p}<0.05$, respectively) (Fig. 5).

CRC samples. Quantitative analysis of the tumor samples demonstrated no differences between the mRNA levels for P1 and $\mathrm{P} 2$ isoforms $(p>0.05)$ in the cancer samples. However, when comparing the levels of $\mathrm{A}, \mathrm{B}$ and $\mathrm{C}$ isoforms, isoform $\mathrm{A}$ was expressed on the same level as isoform $B(p>0.05)$; however, both isoforms demonstrated a significantly higher expression when compared to isoform $\mathrm{C}$ ( $\mathrm{p}<0.001$ in both cases) (Fig. 6).

Quantitative analysis of expression of IGF-1 mRNA isoforms in control and CRC samples. The total expression of IGF-1 mRNA class I and class II determined by P1 and P2 promoters respectively, was significantly higher in the control samples when compared to CRC samples (Table III, Fig. 7). 


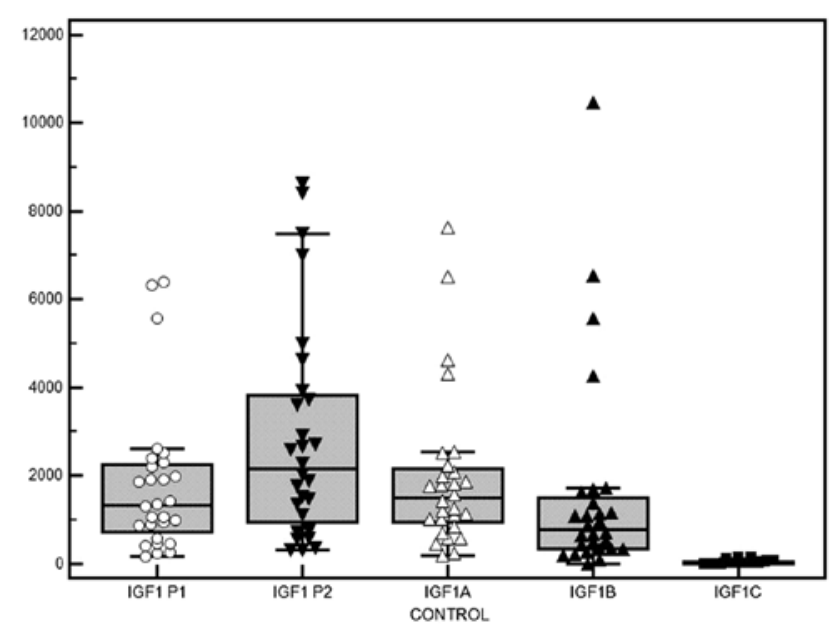

Figure 5. Comparison of quantitative expression involving P1 (class I), P2 (class II), A, B and C IGF-1 mRNA isoforms within non-tumor tissues (control) (data are expressed as the number of mRNA copies $/ \mu \mathrm{g}$ RNA); $>0.05$ between $\mathrm{P} 1$ and $\mathrm{P} 2 ; \mathrm{p}>0.05$ between $\mathrm{A}$ and $\mathrm{B} ; \mathrm{p}<0.01$ between $\mathrm{A}$ and $\mathrm{C}$; $\mathrm{p}<0.05$ between $\mathrm{B}$ and $\mathrm{C}$.

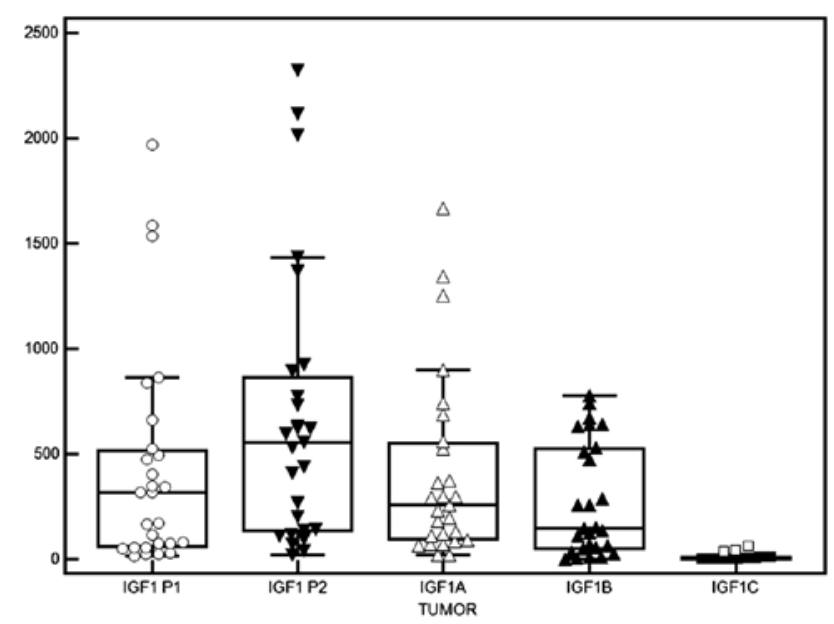

Figure 6. Comparison of quantitative expression involving P1 (class I), P2 (class II), A, B and C IGF-1 mRNA isoforms within CRC tissues (tumor) (data are expressed as the number of mRNA copies/ $\mu$ g RNA); $p>0.05$ between P1 and P2; $>0.05$ between A and B; $<<0.001$ between A and C; $\mathrm{p}<0.001$ between $\mathrm{B}$ and $\mathrm{C}$.

Furthermore, all remaining isoforms, i.e. A, B, and C showed a significantly higher expression in the control compared to the CRC samples (Table III). This finding was supported by the expression of total IGF-1 mRNA which was also higher in the non-tumor samples (Fig. 8).

Analysis of $I G F-1$ transcription showed no differences in promoter usage between the control and CRC samples. The almost equal contribution of P1 $61 \%$ in the control and 59\% in the tumor samples) and $\mathrm{P} 2$ promoters (39\% in the control and $41 \%$ in the CRC samples) was arbitrary assigned to $100 \%$ IGF-1 expression (Fig. 9).

Isoform A of IGF-1 mRNA was the predominant splicing isoform found in CRC samples (82\%). Its expression was significantly higher than that of the isoform obtained for the control samples $(55 \%)(\mathrm{p}<0.03)$. On the other hand, the expression of

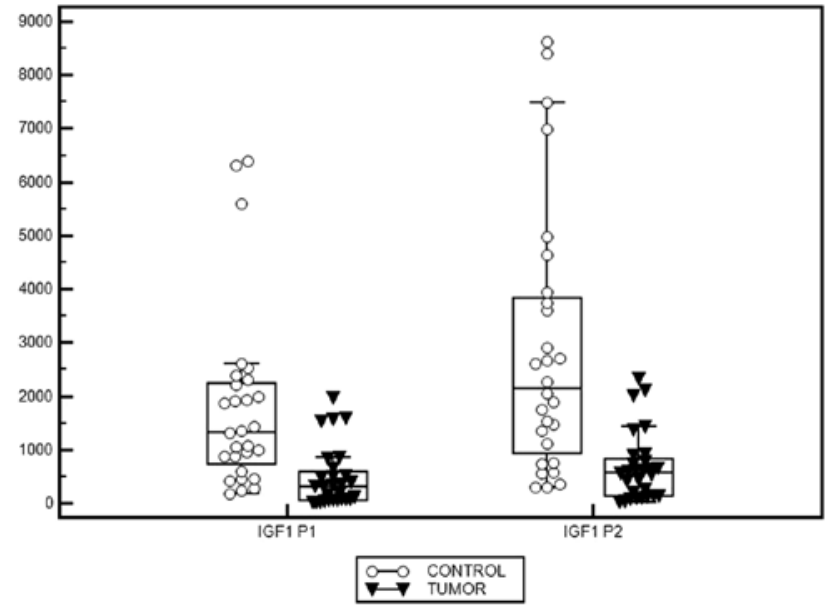

Figure 7. Comparison of quantitative expression involving classes I (P1 promoter) and II (P2 promoter) IGF-1 mRNA isoforms within control and CRC tissues (tumor) (data are expressed as the number of mRNA copies/ $\mu \mathrm{g}$ RNA); $\mathrm{p}<0.001$ between $\mathrm{P} 1$ in the control and the tumor tissues; $\mathrm{p}<0.001$ between expression of $\mathrm{P} 2$ in control and $\mathrm{CRC}$.

Table III. Quantitative comparison between IGF-1 mRNA isoforms and $\mathrm{Ki}-67 \mathrm{mRNA}$ (number of copies $/ \mu \mathrm{g}$ of RNA) in patients with $\mathrm{CRC}$ (tumor) and in non-tumor tissue of the colon (control).

\begin{tabular}{llcc}
\hline $\begin{array}{l}\text { Type of } \\
\text { mRNA }\end{array}$ & Group & Mean \pm SD & P-value \\
\hline IGF-1 P1 & Tumor & $472 \pm 556$ & $<0.001$ \\
& Control & $1806 \pm 1689$ & \\
IGF-1 P2 & Tumor & $673 \pm 640$ & $<0.001$ \\
& Control & $2870 \pm 2461$ & \\
IGF-1 A & Tumor & $1243 \pm 4452$ & $<0.001$ \\
& Control & $1969 \pm 1787$ & \\
IGF-1 B & Tumor & $267 \pm 267$ & $<0.001$ \\
& Control & $1606 \pm 2353$ & \\
IGF-1 C & Tumor & $14 \pm 32$ & $<0.001$ \\
& Control & $40 \pm 41$ & \\
Ki-67 & Tumor & $189355 \pm 189788$ & $>0.05$ \\
& Control & $238523 \pm 189788$ & \\
\hline
\end{tabular}

P-value, level of significance.

IGF-1 B isoform was significantly higher (44\%) in the control tissue when compared to the CRC samples $(17 \%)(\mathrm{p}<0.03)$. The expression of the IGF-1 C isoform was found at the lowest level representing $~ 1 \%$ participation compared to all isoforms analysed in various types of tissue (Fig. 10).

Expression of Ki-67 mRNA in control and CRC samples. No significant differences were found in the expression of Ki-67 mRNA between the control and CRC samples (Table III). Furthermore, no correlations were found between the mRNA and protein expression of $\mathrm{Ki}-67$ either in the control or cancer 


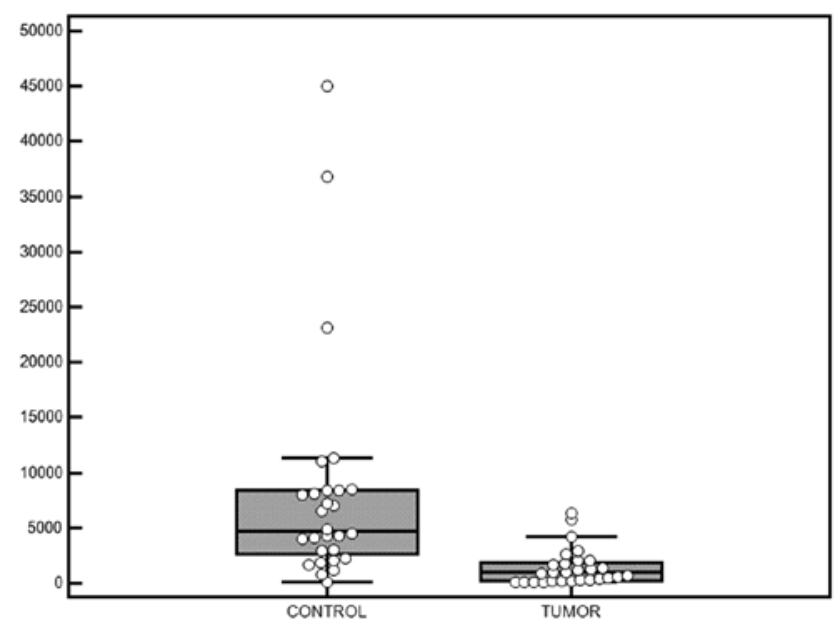

Figure 8. Expression of total IGF-1 mRNA in non-tumor tissues (control), compared to colorectal tumor tissue (data are expressed as the number of mRNA copies/ $\mu \mathrm{g}$ RNA); $\mathrm{p}<0.001$.

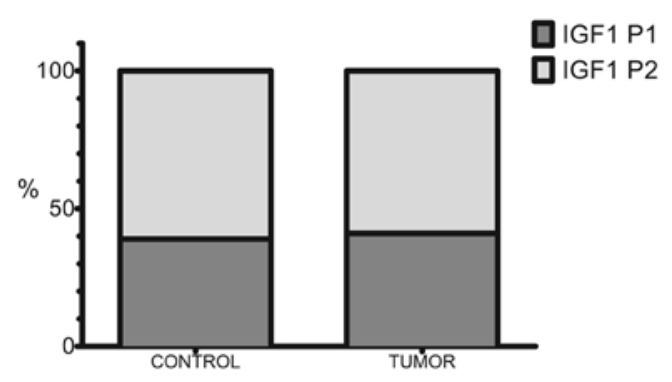

Figure 9. Quantification of $\mathrm{P} 1$ and $\mathrm{P} 2$ promoter activity in non-tumor samples (control), as compared to that of colorectal cancer samples (tumor). IGF-1 mRNA isoforms A, B and C expression was arbitrarily assigned to $100 \%$.

samples ( $r=0.002$ for CRC, $r=-0.201$ for control samples; $\mathrm{p}>0.05$ in both cases) (data not shown).

Correlation between reciprocal expression of different isoforms of IGF-1 mRNA. Highly significant Spearman's correlations were detected between the reciprocal expression of IGF-1 P1 mRNA and P2 mRNA (IGF-1 classes I and II, respectively), between the $I G F-I \mathrm{P} 1$ and $\mathrm{A}, \mathrm{B}, \mathrm{C}$ isoforms as well as between the $I G F-1 \mathrm{P} 2$ transcript and $\mathrm{A}, \mathrm{B}, \mathrm{C}$ isoforms in the control samples (Table IV). The same significant Spearman's correlations were demonstrated in the cancer samples, except for the correlation between the IGF-1 P1 promoter mRNA and isoform B mRNA (Table IV).

Correlation between total $m R N A$ and protein expression of IGF-1. No significant correlations were found between immunocytochemically detected IGF-1 protein expression and amounts of total IGF-1 mRNA ( $\mathrm{r}=-0.068$ for control samples, $\mathrm{r}=0.149$ for $\mathrm{CRC} ; \mathrm{p}>0.05$ in both cases) (data not shown).

Correlation between total IGF-1 and Ki-67 mRNA expression. In non-tumor tissues (control) a direct Pearson's correlation was found between the total IGF-1 mRNA and Ki-67 mRNA

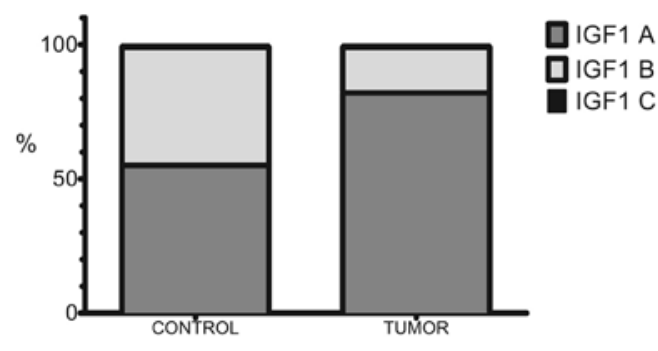

Figure 10. Quantification of IGF-1 mRNA isoform expression (IGF-1 A, IGF-1 B, and IGF-1 C) non-tumor samples, as compared to that of colorectal cancer samples (tumor). IGF-1 mRNA isoforms A, B and C expression was arbitrarily assigned to $100 \%$. The predominant splicing isoform in CRC samples was IGF-1 A (82\%). The proportion was significantly higher than proportion of the isoform in control samples $(55 \%)(\mathrm{p}<0.03)$. The expression of IGF-1 B isoform was significantly higher (44\%) in control tissue as compared with CRC samples $(17 \%)(\mathrm{p}<0.03)$. The expression of IGF-1 C isoform has amounted to $\sim 1 \%$ in both types of tissue examined ( $\mathrm{p}>0.05$ ).

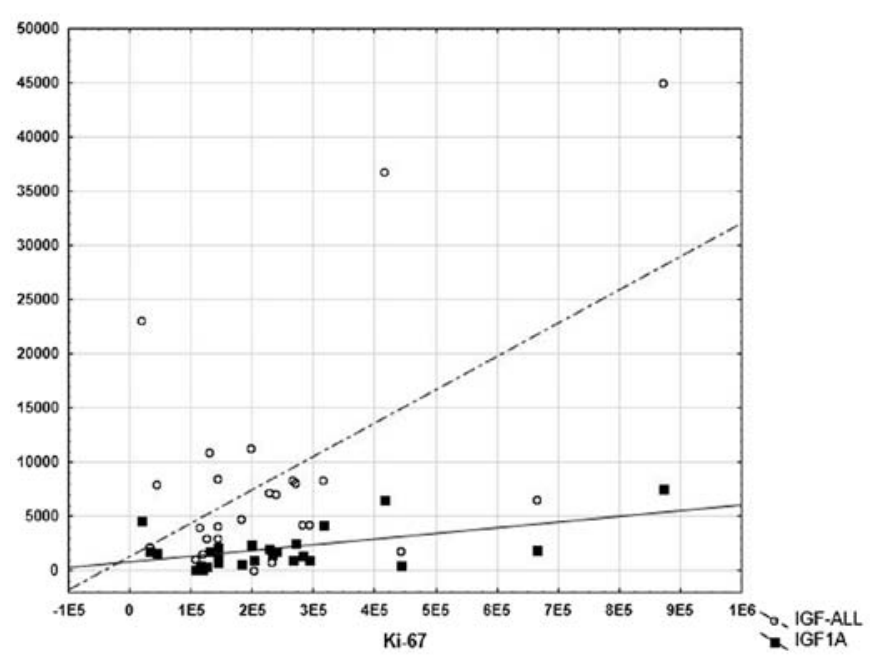

Figure 11. Linear Pearson's correlation between expression of total IGF-1 mRNA and its A isoform on one hand and $\mathrm{Ki}-67 \mathrm{mRNA}$ on the other in non-tumor samples $(r=0.550, r=0.542$, respectively, $\mathrm{p}<0.05) . \mathrm{E} 5,10^{5} ; \mathrm{E} 6$, $10^{6}$.

expression $(r=0.550, p<0.05)$ (Fig. 11). In the case of CRC samples Pearson's correlation between 2 statistical variables proved to be insignificant $(r=0.169 ; p>0.05$; data not shown).

Correlation between expression of IGF-1 and Ki-67 proteins. No significant correlations were found between the protein expression of IGF-1 and Ki-67 in any of analysed tissue groups ( $r=-0.200$ for control samples, $r=-0.067$ for CRC; $p>0.05$ in both cases) (data not shown).

Correlation between IGF-1 expression (total $m R N A$, $m R N A$ isoforms and protein) and clinicopathological data. We observed a faint positive correlation $(\mathrm{r}=0.375, \mathrm{p}<0.05)$ between total IGF-1 mRNA expression in the control samples and patient age. Apart from this, no significant correlation between the expression of IGF-1 (mRNA and protein) and the gender of the patients was observed in any of the groups (data not shown). 
Table IV. Spearman's correlation between reciprocal expression of all examined mRNA isoforms and total IGF-1 mRNA in non-tumor samples (control) and colorectal cancer samples (tumor).

\begin{tabular}{|c|c|c|c|c|c|c|c|c|c|c|}
\hline \multirow[b]{2}{*}{ Isoform } & \multicolumn{2}{|c|}{ IGF-1 P1 } & \multicolumn{2}{|c|}{ IGF-1 P2 } & \multicolumn{2}{|c|}{ IGF-1 A } & \multicolumn{2}{|c|}{ IGF-1 B } & \multicolumn{2}{|c|}{ IGF-1 C } \\
\hline & Control & Tumor & Control & Tumor & Control & Tumor & Control & Tumor & Control & Tumor \\
\hline IGF-1 P1 & - & - & 0.581 & 0.718 & 0.899 & 0.940 & 0.389 & 0.316 & 0.796 & 0.892 \\
\hline IGF-1 P2 & 0.581 & 0.718 & - & - & 0.788 & 0.766 & 0.914 & 0.811 & 0.770 & 0.749 \\
\hline IGF-1 A & 0.899 & 0.940 & 0.788 & 0.766 & - & - & 0.624 & 0.394 & 0.851 & 0.901 \\
\hline IGF-1 B & 0.389 & 0.316 & 0.914 & 0.811 & 0.624 & 0.394 & - & - & 0.696 & 0.433 \\
\hline IGF-1 C & 0.796 & 0.892 & 0.770 & 0.749 & 0.851 & 0.901 & 0.696 & 0.433 & - & - \\
\hline IGF-1 total & 0.885 & 0.845 & 0.481 & 0.742 & 0.761 & 0.794 & 0.297 & 0.518 & 0.714 & 0.829 \\
\hline
\end{tabular}

Bold numbers denote Spearman's rank correlation coefficients $r$, at $\mathrm{p} \leq 0.05$.

No correlation was observed between GF-1 expression (mRNA and protein) and tumor location, macroscopic and microscopic type of the tumor, grading or TNM classification ( $\mathrm{p}>0.05$ in all cases, data not shown).

Ki-67 (mRNA and protein) expression and clinicopathological data of CRC patients. A significantly higher expression of Ki-67 protein was found in tubulous adenocarcinoma (3.19 \pm 0.91$)$ as compared with mucinous/partial mucinous adenocarcinoma $(1.86 \pm 1.57)(\mathrm{p}<0.05)$. A higher expression of $\mathrm{Ki}-67$ was detected in the protruded macroscopic type of tumor $(3.27 \pm 0.88)$ compared to the flat type of the tumor $(2.23 \pm 1.54)(\mathrm{p}<0.05)$. No significant differences were noted in the expression of Ki-67 protein in correlation with tumor location (proximal, distal, $\mathrm{p}>0.05$ ) or grading ( $>0.05)$ (data not shown).

No significant differences in Ki-67 mRNA expression were detected in correlation with the macroscopic or microscopic type of carcinoma, tumor localization, grading or TNM classification ( $\mathrm{p}>0.05$ in all cases) (data not shown).

\section{Discussion}

IGF-1 production in the liver demonstrates mainly endocrine activity while IGF-1 synthesis in other tissues acts in a paraand/or autocrine way $(12,34)$. In experimental models of CRC an autocrine release was demonstrated in all IGF system components including IGF-1, suggesting that the IGF signalling pathway plays a role in colorectal carcinogenesis $(1,45)$. The number of IGFs produced reflects the type of epithelial cells and the type of cellular growth (45). Various transcripts and variable IGF-1 precursor peptides act, first of all, as mitogenic factors but they may also inhibit the growth of neoplastic cells $(17,18,26,27)$.

There remains a paucity of data on the local expression of various splicing isoforms of $I G F-1 \mathrm{mRNA}$ in human tumors $(39,40)$ including CRC (41). In this study, the expression of total mRNA and all splicing isoforms of $I G F-1 \mathrm{mRNA}$ was observed in all the examined CRC and control samples. Existing data on the detection of IGF-1 mRNA vary between the absence of the transcript in CRC tissue (46), HT-29 and CaCo-2 cells (47), its detection in a proportion of cases (41-54\% in CRC and 60-67\% in control samples) (47-49) to its demonstration in all (100\%) CRC and normal colon samples (50), which was supported by our results.

Our study demonstrated quantitative differences in the levels of the expression of IGF-1 total mRNA and its specific isoforms in individual CRC patients and control patients. Statistical analysis revealed a significantly lower mean expression of total IGF-1 mRNA and all its isoforms in CRC as compared to the control samples.

Studies on the level of IGF-1 mRNA expression which were obtained using various quantitative molecular techniques in CRC have also reported variable results $(46,49-51)$. The lack of differences in the expression levels of IGF-1 mRNA in 10 colorectal sporadic cancers (Dukes' stage B or C) as well as in the epithelium scraped from normal colon mucosa was revealed by Michell et al using northern and western blot analysis (50). However, Tricoli et al, using a similar technique (northern blot analysis), reported that $\sim 20 \%$ of the primary colon carcinomas showed higher IGF-1 mRNA expression (3- to 5-fold) while normal colonic mucosa demonstrated only background expression of this mRNA (51).

Nosho et al applied qPCR as we did, and demonstrated IGF-1 mRNA overexpression in $~ 54 \%$ of 90 human colorectal tumor tissues (49). The transcript was only faintly detected in adjacent non-tumor tissues. The expression of IGF-1 mRNA showed a positive correlation with histopathology but not with age, size, gender, location, or macroscopic type of tumor. In contrast to the patients examined by us, they exclusively analysed an early stage of CRC (adenomas and submucosal pT1 CRC) (49). Moreover, they examined total IGF-1 mRNA expression but not the expression of its isoforms and protein. On the other hand, the expression of IGF-1 mRNA evaluated by Jenkins et al was lower in CRC than in control samples $\left(2.6 \times 10^{5}\right.$ vs. $4.7 \times 10^{5}$ copy number $/ \mu$ g total RNA, respectively), which was similar to our results (47).

In interpreting the higher expression of IGF-1 mRNA in control samples, one cannot exclude the theoretical effect of the 'intraluminal' (i.e., dietary) environment, as well as systemic factors on the local production of IGF-1. Thus far, there are no detailed studies available on the regulation of the intestinal IGF system (11). 
In our study, the detection of IGF-1 protein using the immunocytochemical approach revealed its almost equal distribution in the CRC and control samples (50\% vs. $40 \%$, respectively) and no quantitative inter-group differences. The mean expression of the IGF-1 protein was low (below 3 points in the IRS scale) in both groups of tissues. Furthermore, the protein expression of IGF-1 did not correlate with total mRNA levels or individual isoforms expression in any of the analysed groups. A previous study using biochemical methods showed that the IGF-1 protein was present in small amounts and was equally distributed in 19 healthy and 10 malignant tissues (46). We were unable to confirm the results of Bustin et al, that samples which do not express IGF-1 mRNA have no IGF-1 peptide detectable by immunocytochemistry (48).

The comparative examination of specific IGF-1 mRNA isoforms in CRC samples revealed a novel insight since the local expression of IGF-1 mRNA isoforms has not been previously examined in this type of tumor. Using identical primers, all known IGF-1 mRNA isoforms were identified in the genital human papillomavirus (HPV)-positive pre-cancerous, cancerous and HPV-negative control epithelial cells of the cervix (40). Studies have demonstrated the upregulation of all isoforms in pre-cancerous lesions when compared to cervical cancer and control tissues. Additionally, the expression of IGF-1 B isoform was higher in cervical cancer than in the control samples (14 and 8\%, respectively) (40).

Isoform A of IGF-1 mRNA has prevailed over isoforms B and $C(82,17$ and $\sim 1 \%$, respectively) in our study. However, the qPCR technique failed to confirm any significant differences between the expression of isoforms $\mathrm{A}$ and $\mathrm{B}$, although both isoforms were significantly more abundant than isoform $\mathrm{C}$ of IGF-1 in CRC. Similarly, in the control tissues, even though the expression of isoform $\mathrm{B}$ was more pronounced compared to the CRC tissues (44 and 17\%, respectively), the accurate quantitative analysis has failed to detect significant differences between the expression of isoforms $\mathrm{A}$ and $\mathrm{B}$ in the non-tumor tissues. In the CRC and the control samples, isoform $C$ was at its lowest level, which was consistent with the results of Koczorowska et al (40). In contrast to our results, the greatest contribution of the P2 promoter in total IGF-1 expression was observed in the cervical cancer samples (31\%), but the relative expression levels showed no significant differences in promoter usage between the analysed groups (40). In our CRC samples, the IGF-1 P2 contribution was quantified to $51 \%$, similar to the control tissues $(61 \%)$. Similar to the results of Koczorowska et al (40) no quantitative differences were detected in the mRNA expression manifested by the 2 promoters and, thus, the genomic expression of $I G F-1$ seems to remain under the control of P1 and P2 promoters in CRC and in normal tissues of the large intestine. The positive correlation between mRNA IGF-1 P1 expression and A, B (only in control samples) and $\mathrm{C}$ and between mRNA P2 and $\mathrm{A}, \mathrm{B}$ and $\mathrm{C}$ indicates that in $\mathrm{CRC}$ and non-tumor samples, a parallel expression exists between all the IGF-1 mRNA isoforms.

The results of our study demonstrated no significant differences in the amounts of total IGF-1 mRNA and its isoforms which could be associated with the location of adenocarcinoma, macroscopic or microscopic type of the tumor or the remaining clinical and pathological data. These results are in line with those of a previous study (49). We observed a poor positive correlation between the expression of total IGF-1 mRNA in the control samples and patient age. In other words, the local production of IGF-1 mRNA in the normal colon tissue seems to manifest an increasing tendency with progressing age. Moreover, a positive correlation was documented between the expression of total IGF-1 mRNA and the expression of isoform $\mathrm{A}$ and the elevated expression of Ki-67 mRNA in the control tissues. This may point to the role of local IGF-1 production in the stimulation of cell proliferation in the large intestine or to an augmented regenerative potential of normal colon tissues.

The insignificant correlation which we documented between the levels of IGF-1 and Ki-67 transcripts in CRC tissues reflects the analysis of an excessively uniform tissue material (grade 2 in 20 out of 28 patients) and extensive individual differences in the expression of $\mathrm{Ki}-67 \mathrm{mRNA}$. We were unable to corroborate the observations of Bustin et al concerning the correlation between tissue $I G F-1$ mRNA levels and an augmented cell proliferation [examined in the study using the expression of proliferating cell nuclear antigen (PCNA)] in CRC (48).

Even though in our CRC and control tissues, no significant differences were observed between the expression of Ki-67 mRNA in the CRC and control tissue, the tumor samples manifested a significantly higher expression of $\mathrm{Ki}-67$ protein as compared to the control samples. Moreover, a higher expression of the $\mathrm{Ki}-67$ protein was measured in tubulous adenocarcinoma as compared to mucinous/partial mucinous carcinoma and in protruded carcinoma, as compared to the flat macroscopic type of tumor, pointing to a more pronounced cell proliferation in specific microscopic types of CRC. No correlation was observed between $\mathrm{Ki}-67$ and tumor grading and/ or CRC location (proximal, distal). No significant correlations were documented between the expression of IGF-1 protein and the expression of $\mathrm{Ki}-67$ antigen in any of the groups examined.

A comparative examination of specific IGF-1 mRNA isoforms (P1, P2, A, B, C) in human CRC and normal colon tissues provided new data. The expression of total IGF-1 mRNA and all isoforms was documented in normal and malignant colorectal tissues. The expression of all transcripts was significantly decreased in CRC, as compared to the control samples. Positive correlations found between: i) mRNA expression of IGF-1 P1 promoter and both $\mathrm{A}$ and $\mathrm{C}$ isoforms; and ii) $\mathrm{P} 2$ and $\mathrm{A}, \mathrm{B}$ and $\mathrm{C}$ isoform expression. This indicates that a parallel expression exists between all IGF-1 mRNA isoforms in CRC samples. In the control colon tissue material examined, we were able to confirm the existence of a reciprocal correlation between all IGF-1 mRNA variants, as shown in a previous study (41).

Our immunocytochemical analyses confirmed the local cytoplasmic expression of mature IGF-1 protein in only $50 \%$ of patients with CRC and in $\sim 40 \%$ of normal colon tissues. Statistical analysis failed to corroborate a significant correlation between the local production of total IGF-1 mRNA and its isoforms and the presence of mature IGF-1 protein in the analysed groups of tissues. The increased local production of total IGF-1 mRNA with the progressive age of patients and the positive correlation between the expression of total IGF-1 mRNA and isoform A on one hand and Ki-67 mRNA on the other, may provide evidence for an augmented proliferation and an increased regenerative potential in normal colon tissues. 
The results of this study point toward an increased regenerative potential in normal colon tissues which, at least partially, is linked to an elevated expression of total IGF-1 mRNA and its isoform A. In CRC, the local expression of total IGF-1 mRNA and all splicing isoforms of IGF-1 mRNA decreased as compared to normal colon tissues, although however, with conservation of both gene promoter activities and with the continued principal splicing IGF-1 mRNA isoforms.

\section{Acknowledgements}

The study was supported by a grant (no. NN401009437) from the Ministry of Education and Science, Warsaw, Poland.

\section{References}

1. Donovan EA and Kummar S: Role of insulin-like growth factor-1R system in colorectal carcinogenesis. Crit Rev Oncol Hematol 66: 91-98, 2008.

2. Burroughs KD, Donn SE, Barrett JC and Taylor JA: Insulin-like growth factor-I: a key regulator of human cancer risk. J Natl Cancer Res 91: 579-581, 1999.

3. Ma J, Polak MN, Giovannucci E, Chan JM, Tao Y, Hennekens CH and Stampfer MJ: Prospective study of colorectal cancer risk in men and plasma levels of insulin-like growth factor (IGF)-I and IGF-binding protein-3. J Natl Cancer Inst 91: 620-625, 1999

4. Giovanucci E: Insulin-like growth factor-I and binding protein-3 and risk of cancer. Horm Res 51 (Suppl 3): 32-41, 1999.

5. Tennant MK, Thrasher JB, Twomey PA, Drivdahl RH, Birbaum RS and Plymate SR: Protein and messenger ribonucleic acid (mRNA) for the type 1 insulin-like growth factor (IGF) receptor is decreased and IGF-II mRNA is increased in human prostate carcinoma to benign prostate epithelium. J Clin Endocrinol Metab 81: 3774-3782, 1996.

6. Baserga R: The insulin-like growth factor I receptor: a key to tumor growth? Cancer Res 55: 249-255, 1995.

7. Cohen P: Overview of the IGF-I system. Horm Res 65 (Suppl 1): 3-8, 2006.

8. Wu Y, Yakar S, Zhao L, Henninghausen L and LeRoith D: Circulating insulin-like growth factor-I levels regulate colon cancer growth and metastasis. Cancer Res 62: 1030-1035, 2002.

9. Renehan AG, Zwahlen M, Minder C, O'Dwyer ST, Shalet SM and Egger M: Insulin-like growth factor (IGF)-I, IGF binding protein-3, and cancer risk: systematic review and meta-regression analysis. Lancet 363: 1346-1353, 2004.

10. Rinaldi S, Cleveland R, Norat T, et al: Serum levels of IGF-I, IGFBP-3 and colorectal cancer risk: results from EPIC cohort, plus a meta-analysis of prospective studies. Int J Cancer 126: 1702-1715, 2010.

11. Renehan AG, O'Dwyer ST and Ahalet SM: Re: Prospective study of colorectal cancer risk in men and plasma levels of insulin-like growth factor (IGF)-I and IGF-binding protein-3. J Natl Cancer Res 91: 2051-2052, 1999.

12. Daughday WH and Rotwein P: Insulin-like growth factors I and II. Peptide, messenger ribonucleic acid and gene structures, serum and tissue concentrations. Endocr Rev 10: 68-91, 1989.

13. Jones JI and Clemmons DR: Insulin-like growth factors and their binding proteins: biological functions. Endocr Rev 13: 3-34, 1995.

14. Murphy LJ: Insulin-like growth factor-binding proteins: functional diversity or redundancy? J Mol Endocrinol 21: 97-107, 1998 .

15. Bell GI, Stempien MM, Fong NM and Rall LB: Sequences of liver cDNAs encoding two different mouse insulin-like growth factor 1 precursors. Nucleic Acids Res 14: 7873-7882, 1986.

16. Adamo ML: Regulation of insulin-like growth factor I gene expression. Implications for normal and pathological growth. Diabetes Rev 3: 2-27, 1995.

17. Temmerman L, Slonimsky E and Rosenthal N: Class 2 IGF-1 isoforms are dispensabile for viability, growth and maintenance of IGF-1 serum levels. Growth Horm IGF Res 20: 255-263, 2010.

18. Matheny RW Jr, Nindl BC and Adamo ML: Minireview: Mechano-Growth Factor: a putative product of IGF-I gene expression involved in tissue repair and regeneration. Endocrinology 151: 865-875, 2010.
19. Adamo ML, Ben-Hur H, LeRoith D and Roberts CT Jr: Transcription initiation in the two leader exons of the rat IGF-1 gene occurs from disperse versus localized sites. Biochem Biophys Res Commun 176: 887-893, 1991.

20. Simmons JG, Van Wyk JJ, Hoyt EC and Lund PK: Multiple transcription start sites in the rat insulin-like growth factor-I gene give rise to IGF-I mRNAs that encode different IGF-I precursors and are processed differently in vitro. Growth Factors 9: 205-221, 1993.

21. Jansen M, van Schaik FM, Ricker AT, et al: Sequence of cDNA encoding human insulin-like growth factor I precursor. Nature 306: 609-611, 1983.

22. Rotwein P: Two insulin-like growth factor I messenger RNAs are expressed in human liver. Proc Natl Acad Sci USA 83: 77-81, 1986.

23. Shavlakadze T, Winn N, Rosenthal N and Grounds MD: Reconciling data from transgenic mice that overexpress IGF-I specifically in skeletal muscle. Growth Horm IGF Res 15: 4-18, 2005.

24. Chew SL, Lavender P, Clark AJ and Ross RJ: An alternatively spliced human insulin-like growth factor-1 transcript with hepatic tissue expression that diverts away from mitogenic IBE1 peptide. Endocrinology 136: 1939-1944, 1995.

25. Rotwein P, Pollock KM, Didier DK and Krivi GG: Organization and sequence of the human insulin-like growth factor I gene. Alternative RNA processing produces two insulin-like growth factor I precursor peptides. J Biol Chem 261: 4828-4832, 1986.

26. Tian XC, Chen MJ, Pantschenko AG, Yang TJ and Chen TT: Recombinant E-peptides of pro-IGF-I have mitogenic activity. Endocrinology 140: 3387-3390, 1999.

27. Chen MJ, Chiou PP, Lin P, Lin CM, Siri S, Peck K and Chen TT: Suppression of growth and cancer-induced angiogenesis of aggressive human breast cancer cells (MDA-MB-231) on the chorionallantoic membrane of developing chicken embryos by E-peptide of pro-IGF-I. J Cell Biochem 101: 1316-1327, 2007.

28. Siegfried JM, Kasprzyk PG, Treston AM, Mulshine JL, Quinn KA and Cuttitta F: A mitogenic peptide amide encoded within the E peptide domain of the insulin-like growth factor IB prohormone. Proc Natl Acad Sci USA 89: 8107-8111, 1992.

29. McKoy G, Ashley W, Mander J, Yang SY, Williams N, Russell B and Goldspink G: Expression of insulin-like growth factor-1 splice variants and structural genes in rabbit skeletal muscle induced by stretch and stimulation. J Physiol 516: 583-592, 1999.

30. Hameed M, Lange KH, Andersen JL, Schjerling P, Kjaer M, Harridge SD and Goldspink G: The effect of recombinant human growth hormone and resistance training of IGF-I mRNA expression in the muscles of elderly men. J Physiol 555: 231-240, 2004.

31. Vinciquerra M, Santini MP, Claycomb WC, Ladurner AG and Rosenthal N: Local IGF-1 isoform protects cardiomyocytes from hypertrophic and oxidative stresses via Sirtl activity. Aging (Albany NY) 2: 43-62, 2009.

32. Adamo ML, Neuenschwander S, LeRoith D and Roberts CT Jr: Structure, expression, and regulation of the IGF-I gene. Adv Exp Med Biol 343: 1-11, 1993.

33. Zarilli R, Bruni CB and Riccio A: Multiple levels of control of insulin-like growth factor gene expression. Mol Cell Endocrinol 101: R1-R14, 1994.

34. Alexia C, Fallot G, Lasfer M, Schweizer-Groyer G and Groyer A: An evaluation of the role of insulin-like growth factors (IGF) and of type-I IGF receptor signalling in hepatocarcinogenesis and in the resistance of hepatocellular cells against drug-induced apoptosis. Biochem Pharmacol 86: 1003-1015, 2004.

35. Samani AA, Yakar S, LeRoith D and Brodt P: The role of the IGF system in cancer growth and metastasis: overview and recent insights. Endocr Rev 28: 20-47, 2007.

36. Garrouste F, Remacle-Bonnet M, Fauriat C, Marvaldi J, Luis J and Pommier G: Prevention of cytokine-induced apoptosis by insulin-like growth factor-I is independent of cell adhesion molecules in HT29-D4 colon carcinoma cells-evidence for a NF-kappaB-dependent survival mechanism. Cell Death Differ 9: 768-779, 2002.

37. Akagi Y, Liu W, Zebrowski B, Xie K and Ellis LM: Regulation of vascular endothelial growth factor expression in human colon cancer by insulin-like growth factor-I. Cancer Res 58: 4008-4014, 1998.

38. Andre F, Rigot V, Thimonier J, et al: Integrins and E-cadherin cooperate with IGF-I to induce migration of epithelial colonic cells. Int J Cancer 83: 497-505, 1999. 
39. Armakolas A, Philippou A, Panteleakou Z, Nezos A, Sourla A Petraki $\mathrm{C}$ and Koutsilieris M: Preferential expression of IGF-IEc (MGF) transcript in cancerous tissues of human prostate: evidence for a novel and autonomous growth factor activity of MGF E peptide in human prostate cancer cells. Prostate 70 : 1233-1242, 2010.

40. Koczorowska MM, Kwasniewska A and Gozdzicka-Jozefiak A: IGF1 mRNA isoform expression in the cervix of HPV-positive woman with pre-cancerous and cancer lesions. Exp Ther Med 2: 149-156, 2011.

41. Kasprzak A, Szaflarski W, Szmeja J, et al: Expression of various insulin-like growth factor-1 mRNA isoforms in colorectal cancer. Wspol Onkol 16: 147-153, 2012.

42. Hsu SM, Raine L and Fanger H: Use of avidin-biotin-peroxidase complex (ABC) in immunoperoxidase techniques: a comparison between $\mathrm{ABC}$ and unlabeled antibody (PAP) procedures. J Histochem Cytochem 29: 577-580, 1981.

43. Remmele W and Stegner HE: Recommendation for uniform definition of an immunoreactive score (IRS) for immunohistochemical estrogen receptor detection (ER-ICA) in breast cancer tissue. Pathologe 8: 138-140, 1987 (In German).

44. Gatter KC, Dunnill MS, Gerdes J, Stein H and Mason DY: New approach to assessing lung tumors in man. J Clin Pathol 39 590-593, 1986.

45. Jehle PM, Fussgaenger RD, Blum WF, Angelus NK, Hoeflich A, Wolf $E$ and Jungwirth RJ: Differential autocrine regulation of intestine epithelial cell proliferation and differentiation by insulin-like growth factor (IGF) system components. Horm Metab Res 31: 97-102, 1999.
46. Freier S, Weiss O, Eran M, et al: Expression of the insulingrowth factors and their receptors in adenocarcinoma of the colon. Gut 44: 704-708, 1999.

47. Jenkins PJ, Khalaf S, Ogunkolade W, et al: Differential expression of IGF-binding protein-3 in normal and malignant colon and its influence on apoptosis. Endocr Relat Cancer 12: 891-901, 2005.

48. Bustin SA, Dorudi S, Phillips SM, Feakins RM and Jenkins PJ: Local expression of insulin-like growth factor-I affects angiogenesis in colorectal cancer. Tumor Biol 23: 130-138, 2002.

49. Nosho K, Yamamoto H, Taniguchi H, et al: Interplay of insulinlike growth factor-II, insulin-like growth factor-I, insulin-like growth factor-I receptor, COX-2, and matrix metalloproteinase-7, play key roles in the early stage of colorectal carcinogenesis. Clin Cancer Res 10: 7950-7957, 2004.

50. Michell NP, Langman MJS and Eggo MC: Insulin-like growth factors and their binding protein in human colonocytes: preferential degradation of insulin-like growth factor binding protein 2 in colonic cancers. Br J Cancer 76: 60-66, 1997.

51. Tricoli JV, Rall LB, Karakousis CP, Herrera L, Petrelli NJ, Bell GI and Shows TB: Enhanced levels of insulin-like growth factor messenger RNA in human colon carcinomas and liposarcomas. Cancer Res 46: 6169-6173, 1986. 